\title{
GENRE FOTOGRAFI YANG DIMINATI OLEH FOTOGRAFER DI INDONESIA
}

\author{
Agnes Paulina Gunawan \\ Visual Communication Design, School of Design, BINUS University \\ Jln. K.H. Syahdan No. 9, Palmerah, Jakarta Barat 11840 \\ agunawan@binus.edu
}

\begin{abstract}
When speaking of progress, photography is one of the things that is experiencing a quite vast development, and relatively wide in terms of technology or its visual feature. What it means by visual feature here is that in a long period of time, a lot has changed in its idea or concept. Also, it means the print media, or even its printing technique. Moreover he most basic of all is its character of the result in the photo itself. Whether the object taken, moment or time of the photo shoot, all these factors quite represent several genres in photography. For example, if the photography is making a human being to become its model, it might mean a modeling photo shoot, kids, or family photo shoot. Also it might mean a studio/indoor photo shoot or an outdoor photo shoot, when speaking of genre category. If the photo taken is a moment or an event, it might be a journalistic genre or a documentation one. Several themes or visual feature in a photo shoot will become one of the aspects for us the subject to be able to categorize the kind of genre they are. Hence, those genres definitely serve different functions.
\end{abstract}

Keywords: photography by genre, types of photography, functions of photography

\begin{abstract}
ABSTRAK
Dalam perkembangannya, bidang fotografi mengalami perkembangan yang cukup pesat, dan relatif luas, baik secara teknologi maupun secara tampilan visual. Tampilan visual yang dimaksud antara lain karya fotografi dalam kurun waktu yang cukup lama banyak berkembang dari segi ide atau konsep, segi tampilan, media cetak, teknik cetak, dan yang paling mendasar adalah karakter dari hasil pemotretan. Objek yang dipotret dan momen atau waktu pemotretan, faktor ini cukup mewakili beberapa genre atau aliran dalam bidang fotografi. Misalnya, karya fotografi yang menampilkan manusia sebagai model, bisa saja itu adalah fotografi model; atau fotografi anak-anak atau foto keluarga juga bisa termasuk kategori genre foto studio atau foto outdoor. Jika dalam karya foto itu yang disampaikan adalah suatu momen atau suatu kejadian, bisa jadi itu adalah genre foto jurnalistik atau foto dokumentasi. Macam-macam tema atau tampilan visual yang terekam dalam sebuah karya foto tadi menjadi salah satu aspek yang dapat menjadi acuan bagi pengamat foto untuk dapat mengategorikan jenis atau aliran karya foto. Genre-genre tersebut memiliki fungsi yang pada dasarnya berbeda-beda penggunaannya.
\end{abstract}

Kata kunci: genre fotografi, aliran fotografi, fungsi fotografi 


\section{PENDAHULUAN}

Dalam bidang fotografi, fotografer bisa merekam semua objek yang terdapat di alam dan di lingkungan sekitarnya. Banyak sekali objek foto yang bisa direkam dan diabadikan dalam sebuah karya fotografi, baik yang di-setting atau dikondisikan, maupun yang candid atau yang diambil berdasarkan momen yang terjadi dalam suatu kejadian. Dari semuanya fotografer bisa memilih objek yang bergerak maupun mahkluk hidup maupun objek yang diam, juga termasuk benda mati. Artikel membahas tentang beberapa aliran atau genre dalam bidang fotografi yang dalam kurun waktunya, berkembang dan memiliki komunitas penggemarnya sendiri-sendiri, dan juga memiliki pengembangan yang mungkin didasari dengan adanya adaptasi genre yang sudah ada, dengan budaya lokal terutama di Indonesia.

Karena perkembangan aliran atau genre dalam fotografi ini sangatlah luas dan beragam, yang akan dibahas dalam artikel ini lebih dikhususkan untuk berbagi informasi umum mengenai masingmasing aliran yang cukup dikenal dimasyarakat dan komunitas fotografi Indonesia, dengan bahasan yang sederhana dan contoh foto yang umumnya dikenal dalam aliran tersebut. Hal ini disebabkan begitu banyaknya pendapat dan pembagian fotografi dalam genre-genre yang seandainya ditelaah dengan serius masih cukup banyak yang pro dan kontra dalam pengategoriannya, disesuaikan dengan fungsinya saat penggunaan tujuan karya foto tersebut.

Umumnya masyarakat sering kurang menyadari bahwa hal-hal yang ada di sekelilingnya cukup banyak menggunakan karya fotografi sebagai media perantara untuk menjembatani suatu visual tertentu dalam banyak aspek saat ini. Bahkan, karena relatif cukup familiar dengan karya-karya fotografi dengan aliran-aliran yang berbeda, masyarakat bahkan tidak menyadari bahwa apa yang mereka amati tadi adalah suatu karya foto. Hal ini ternyata banyak dialami dalam masyarakat awam di Indonesia karena keterbatasan informasi dan pengetahuan mereka mengenai tentang dunia fotografi yang memiliki banyak aliran atau genre.

Bila berkomunikasi dengan masyarakat awam yang tidak memiliki ketertarikan dalam bidang fotografi, lazimnya mereka hanya menganggap karya fotografi itu mayoritas adalah foto-foto portrait dengan model yang tampak glamor, tampak mewah, dengan baju dan dandanan yang bagus. Ilustrasi ini adalah opini nyata dari masyarakat terutama menengah kebawah, yang bila ditanya tentang karya fotografi mereka berasumsi pada foto-foto kalender dengan artis atau model. Atau foto keluarga yang tertata rapi dan berbaris, termasuk foto saat wisuda, juga karya foto dokumentasi acara pernikahan. Saat mereka melihat foto pemandangan alam dengan pantai atau alam, mereka jarang mengasumsikan image tersebut sebagai karya foto. Mereka juga tidak menyadari bahwa karya foto yang mereka lihat dalam sebuah buku katalog yang berisi beraneka ragam alat kosmetik pada katalog agen penjual multilevel. Apalagi saat melihat iklan kendaraan bermotor dalam sebuah papan reklame, mereka menganggap tampilan visual tadi hanya sebagai merk suatu produsen kendaraan bermotor saja. Hal ini disebabkan kurangnya informasi mengenai aliran dalam bidang fotografi.

\section{METODE}

Penulisan ini disusun sebagai hasil dari penelitian kualitatif dengan pendekatan melalui metode studi literatur. Pengumpulan data dilakukan melalui buku dan artikel yang membahas tentang teori fotografi, buku tentang fotografi, serta sumber dari Internet mengenai teori yang berkaitan dengan materi pembahasan. Penelitian juga didukung pengalaman dan proses praktik serta informasi dari praktisi fotografi dan desain di bidang yang berkaitan. 


\section{HASIL DAN PEMBAHASAN}

Dalam perkembangannya, bidang fotografi di Indonesia saat ini berkembang sangat pesat terutama dengan perkembangan dan inovasi-inovasi baru dalam tehnologi peralatannya. Sehingga pada masa sekarang hampir pasti semua orang memiliki pengetahuan tentang fotogafi. Namun informasi atau pemahaman tentang bidang fotografi ini, biasanya beraneka ragam, tergantung dengan lingkungan masing-masing orang. Informasi tentang bidang fotografi yang paling sederhana adalah karya foto potret seseorang.

Dimulai dari pasfoto sederhana, maupun foto studio dengan model manusia, bahkan di kalangan masyarakat menengah ke bawah atau pedesaan, mereka bisa melihat suatu karya foto pada spanduk saat pemilihan calon kepala desa, atau caleg, sampai calon presiden, melalui foto portrait calon pemimpin yang sedang berkampanye. Bahkan tanpa disadari semua lapisan masyarakat paling mudah menemukan genre fotografi komersial, pada saat mereka melihat suatu iklan, baik di sebuah swalayan, atau spanduk di warung, atau sekadar papan reklame besar di pinggir jalan, yang kadang memampangkan produk minuman, kadang mengiklankan suatu jenis makanan ringan, atau saat produk teknologi baru akan dijual dipasaran. Atau saat masyarakat membaca berita di koran, dan mendapatkan informasi tentang olah raga, atau tentang politik, atau karya fotografi tentang wisata kuliner, sehingga para pembaca koran bisa mencoba mendapatkan gambaran mengenai situasi kondisi ataupun bentuk dari suatu tema yang sedang dibahas dalam suatu berita dikoran tersebut.

Dalam perkembangannya, seni fotografi juga mengalami perluasan dan pengembangan dari hasil eksploitasi dan kekreatifitasan para senimannya yaitu para fotografer sendiri. Dari banyaknya faktor pencetus baik kebutuhan pasar, perubahan jaman, situasi politik, ataupun faktor yang menjadi reaksi atas perkembangan seni yang lain, maka genre dalam fotografi bisa bertambah banyak. Yang dulunya hanya terbagi dalam aliran atau gaya pemotretan saja, sekarang sudah bisa dipilah dalam kategori aliran berdasarkan jenis media rekamnya, misalnya dulu semua karya foto berasal dari hasil kamera, namun sekarang dengan perkembangan tehnologi karya fotografi ada yang dikategorikan dalam genre foto dengan smartphones. Bahkan perkembangan ini juga menciptakan profesi baru yang berhubungan dengan bidang fotografi selain fotografernya, misalnya asisten fotografer, make up artist dalam bidang fashion, food stylish dalam bidang foto makanan, atau pun digital artist untuk mengolah data digital dalam karya komersial (Felix, 2011).

Bahkan sarana untuk menjadi media presentasinya pun mulai beragam, tidak hanya karya foto yang berupa cetakan, tetapi sekarang bisa dinikmati dalam media digital. Namun tetap, waktu pengambilan suatu foto merupakan hal yang sangat penting yang akan menjadi inti dari foto tersebut, baik itu foto dengan waktu pemotretan yang sangat singkat seperti foto jurnalistik atau foto olahraga maupun dengan waktu yang relatif lama seperti jenis-jenis foto lanskap yang bisa menghabiskan waktu dari matahari tinggi sampai matahari tenggelam (Freeman, 2007). Kemampuan dan kepekaan seseorang dalam mengambil rekaman visual dalam foto itu akan menjadi salah satu nilai ukur dalam keanekaragaman aliran yang ada.

\section{Genre}

Genre, yang biasanya sebagian orang menyebut dengan aliran, atau ada juga yang menyebut dengan gaya, atau tipe, adalah suatu pengategorian atau pengelompokan sesuatu hal. Istilah kata genre diadaptasi dari pelafalan dalam bahasa Perancis yang berarti 'jenis' atau 'semacam' yang dalam perkembangannya menjadi istilah untuk suatu kategori dalam sebuah karya seni, termasuk dalam literatur atau seni sastra, dan bentuk lain dari seni dan bidang hiburan , misalnya bidang musik, maupun suatu karya tulis atau lisan, karya audio atau visual. Dalam pengelompokannya genre ini didasarkan pada beberapa jenis kriteria gaya atau karakter. Genre pada praktik pengembangannya sering ditentukan dari hasil kesepakatan berdasar beberapa aspek yang mendasari pengkategorian itu, 
yang dapat berubah dari waktu ke waktu. Pada dasarnya seiring dengan perjalanan waktu, suatu genre bisa berkembang menjadi genre baru, kadang-kadang bisa menggantikan paham atau prisip genre yang lama, atau bisa juga berkembang menjadi cabang atau menghasilkan prinsip genre yang baru.

Genre ini pada awalnya menjadi salah satu sistem klasifikasi pengkategorian karya seni sastra dalam jaman Yunani kuno. Karya puisi, prosa, ataupun dalam suatu pertunjukan seni, terikat dalam suatu tatanan yang khusus dan teratur yang disesuaikan dengan tema utama dari cerita karya yang ditampilkan. Misalnya pola gaya pembacaan atau pembawaan untuk tema komedi tidak akan cocok untuk menyampaikan tema tragedi. Dalam masa-masa selanjutnya, suatu genre akan berkembang menghasilkan cabang-cabang genre yang baru sebagai suatu reaksi untuk merespons perkembangan dan perubahan dari para pencipta seni dan juga penikmat seni yang akan terus berkembang.

Genre ini akan menjadi suatu media atau alat yang dinamis untuk membantu masyarakat awam dalam mencoba memahami atau mungkin menikmati perkembangan suatu karya seni yang kadang tidak dapat di prediksi atau tidak mudah dipahami langsung oleh masyarakat sebagai penikmat seni. Sebab karya seni sering kali didasari atau menjadi suatu reaksi untuk merespons perubahan yang terjadi dalam masyarakat, melalui karya seni banyak orang yang memposisikan diri sebagai seniman menghasilkan karya tulis, karya lukis, nyanyian, tarian dan seni yang lain sebagai bentuk respons terhadap perkembangan yang bergulir dalam kehidupan masyarakat dan lingkungannya. Dalam mengadaptasi perubahan-perubahan atas respons yang terjadi tadi, sering kali terbentuk hal-hal yang baru dalam karya seni, sehingga disinilah genre akan berkembang, yang akan menghasilkan aliran atau gaya atau tipe yang baru, bisa jadi perkembangan dari genre yang lama, bisa juga bertolak belakang dari genre yang sudah ada.

Perkembangan proses perubahan dari karya-karya seni yang dihasilkan oleh para seniman tadi membutuhkan periode waktu yang signifikan, umumnya diawali dengan sesuatu karya yang unik ataupun relatif baru yang diikuti dengan respons dan tanggapan lingkungan yang ada dijaman tersebut, direspons dan bergulir diantara masyarakat, dan dengan respons positif ataupun negatif, terbentuklah reaksi pro dan kontra. Termasuk banyaknya karya-karya yang mengikuti keunikan tersebut, dan menghasilkan sekelompok karya dengan gaya dan ide yang berawal dengan konsep dasar yang sama, perkembangan komunitas ini yang makin meluas dan berkolaborasi dengan situasi kondisi dimasingmasing tempat dan dikalangan masyarkat, inilah yang dapat menjadi awal sebuah genre baru. Yang tentunya bila pro kontra makin banyak dan meluas, genre tersebut akan tersebar dibagian yang lebih luas dan akan mengalami perubahan dan juga penyesuaian dengan lingkungan dimana masyarakat tersebut berkembang. Misalnya suatu genre yang mengalami akulturasi karakter dengan budaya lokal atau adat istiadat setempat.

Genre dalam sebuah karya seni, umumnya merupakan hasil proses pengolahan emosi atau ide yang menjadi reaksi dari tren disuatu masa dengan kurun waktu yang relatif lama. Lahirnya sebuah genre biasanya didasari oleh banyak faktor, antara lain kebutuhan pasar, taraf hidup masyarakat, tren politik di suatu masa, atau penggabungan ide dan pengembangan kreatifitasan seniman-seniman yang terus berkembang tanpa bisa diprediksi dan tanpa ada batasannya.

\section{Genre Fotografi}

Dalam bidang fotografi, seorang fotografer yang memiliki cukup pengetahuan atau cukup mengenal genre atau aliran dalam fotografi ini, pasti akan lebih mudah untuk memahami ketertarikan atau peminatannya dalam bidang fotografi dan akan mempermudah si fotografer untuk lebih memahami arah dan peluang yang terbuka untuknya dalam mengembangkan karir, hobi atau kemampuannya di bidang fotografi ini.

Bila mau ditekuni, untuk mengklasifikasi aliran-aliran fotografi ini relatif sukup sulit. Dimulai dengan bagaimana cara mengamati suatu aliran penggunakan tehnik apa, apakah suatu karya foto 
portrait yang sedang diamati, menggunakan tehnik pemotretan portraiture atau sebuah foto portrait saja. Bahkan akan ada hasil karya foto yang dalam praktiknya bisa dilihat dalam lebih dari satu aliran, sehingga akan sulit untuk pengamat dalam mengkategorikan karya itu termasuk dalam aliran atau genre apa. Sehingga seperti yang telah disinggung sebelumnya jurnal ini hanya menginformasikan contoh-contoh yang umumnya menjadi karakter sebuah genre atau aliran namun bukan merupakan sesuatu teori yang baku. Yang terpenting dalam memilah kategori aliran fotografi salah satunya membahas dalam forum atu berdiskusi, sehingga komentara atau analisa dari lebih dari seorang akan membuat suatu karya menjadi lebih mudah untuk diseleksi.

Banyak pendapat yang berusaha memberikan aspek dalam mempermudah pengategorian ini, antara lain pemilahan berdasarkan objek fotonya, misalnya: Manusia, bisa foto studio/indoor, foto model, beauty shot, foto perkawinan, foto prewedding, foto anak dan balita, foto candid, dan lain-lain; Flora dan Fauna, bisa foto makro (foto yang sangat detail atau close up), bisa foto alam, foto bawah laut, foto hewan atau yang dikenal wildlife; Pemandangan, bisa foto alam, bisa foto aerial; Bangunan, bisa foto arsitektural, foto interior; Benda, bisa foto makanan (food photography), foto still life. Masih banyak pendapat lain yang mungkin lebih mendetail dalam pengategorian aliran-aliran ini. Berikut ini adalah beberapa pendapat mengenai aliran atau genre untuk karya fotografi terutama yang cukup dikenal di kalangan peminat fotografi di Indonesia.

Fotografi jurnalistik adalah bentuk khusus dari jurnalisme yang menciptakan gambar agar dapat menceritakan sebuah kisah yang melengkapi sebuah berita, biasanya foto jurnalistik yang baik sudah dapat menceritakan banyak hal hanya dari visual fotonya. Kadang bisa bersifat objektif kadang bersifat subjektif. Keunggulan sebuah foto yang mengandung berita banyak ditentukan oleh apakah berita tersebut benar-benar mempunyai nilai meskipun sering kali sangat bersifat subjektif tergantung dari siapa yang melihat dan memanfaatkannya.

Berita adalah laporan yang tepat waktu mengenai segala sesuatu yang menarik perhatian orang dan berita terbaik adalah yang menarik sebagian besar pembaca. Berita adalah laporan yang baru tentang peristiwa, pendapat atau masalah yang menarik perhatian sebanyak-banyaknya orang. Sedangkan foto jurnalistik adalah foto yang membuat berita dengan menggunakan foto tersebut sebagai media informasi tadi.

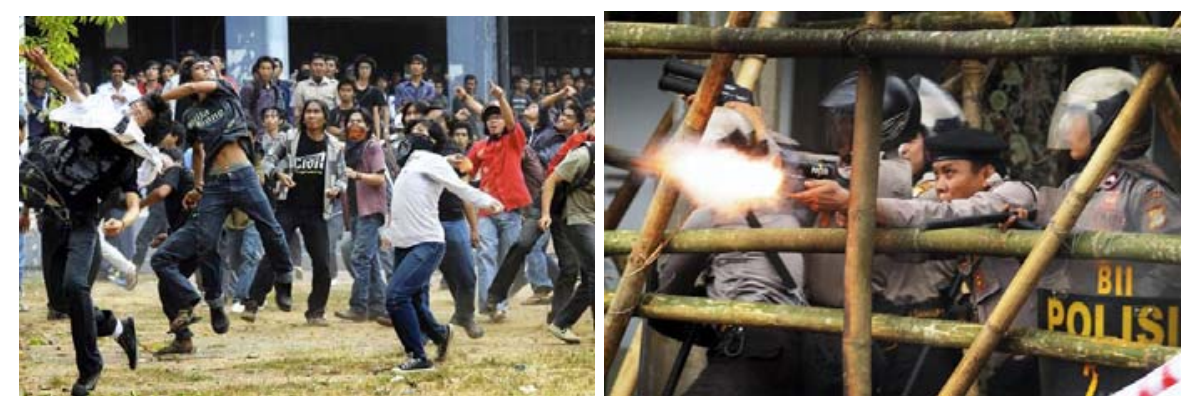

Gambar 1 Fotografi Jurnalistik

(Sumber: Antara-Sahrul Manda Tikupadang dan Antara-Yusran Uccang)

Pada saat seseorang memutuskan belajar foto jurnalistik, dia akan masuk ke sebuah daerah yang terdapat sebuah tradisi kuat untuk menyampaikan 'sesuatu' (berita) kepada orang lain (publik). Seperti yang dilakukan oleh fotografer seni, seorang wartawan foto harus mempunyai sentuhan artistik untuk menghasilkan image yang menyengat namun selalu sigap dan cepat mengabadikan semuanya dalam waktu yang sangat singkat tanpa berpikir tentang konsep, komposisi, dan teori-teori lain, sehingga tantangannya sangat besar. 
Henri Cartier-Bresson, salah satu pendiri agen foto terkemuka, Magnum, yang terkenal dengan teori Decisive Moment --menjabarkan, "foto jurnalistik adalah berkisah dengan sebuah gambar, melaporkannya dengan sebuah kamera, merekamnya dalam waktu, yang seluruhnya berlangsung seketika saat suatu citra muncul mengungkap sebuah cerita."

Fotografi still life, pemotretan dengan objek benda mati yang difoto dengan keseriusan sehingga benda yang difoto akan nampak lebih artistik dengan bebrapa usaha yang lebih, misalnya dengan menggunakan cahaya tambahan, atau dengan menggunakan lensa yang khusus (misalnya lensa makro). Umumnya masyarakat beranggapan bahwa fotografi stillife ini memiliki tingkat kesulitan yang relatif rendah bila dibandingkan dengan fotografi jurnalistik atau fotografi olahraga (sport). Dari arti katanya still yang artinya diam atau mati, sedangkan life berarti hidup dalam konteks memberi "kehidupan" pada benda tersebut. Still life photography dapat diartikan memotret benda mati tampak lebih hidup dan berbicara. Foto still life bukan hanya memindahkan objek kedalam sebuah foto, tetapi lebih dapat mengandung arti dengan pencapaian hasil foto yang lebih artistik dan bermakna.

Dalam fotografi still life ini, tantangan terbesar dari fotografer adalah membuat benda yang difoto lebih menarik dari aslinya atau memikirkan konsep yang menarik untuk pemotretan itu. Keuntungan terbesar dalam memotret benda mati adalah fotografer bisa menguasai penuh bidang gambar yang akan terfoto, fotografer bisa memaksimalkan komposisi, sudut pengambilan dan arah pencahayaan sepenuhnya.

Biasanya salah satu guna foto still life menjadi pemotretan benda untuk tujuan pembuatan katalog, brosur, company profile, flyer, dan iklan. Dalam hal ini, still life berfungsi sebagai iklan atau komunikasi visual dalam konteks komersial. Semua foto yang dibuat harus komunikatif; seberapa bagus desain barangnya, bagaimana fungsi barangnya dan diperuntukkan untuk kalangan siapa barang yang ada dalam foto tersebut.

Namun dalam konsep yang berbeda, foto still life dibuat sesuai selera, konsep dan emosi fotografer yang membuat foto still life tersebut. Seorang fotografer dapat mengekspresikan diri ke dalam fotonya. Biasanya hasil dari foto ini lebih rumit dibandingkan hanya memotret benda tadi secara fisiknya. Biasanya hasil karya foto ini, tidak selalu menampilkan wujud sebenarnya dari benda tersebut.

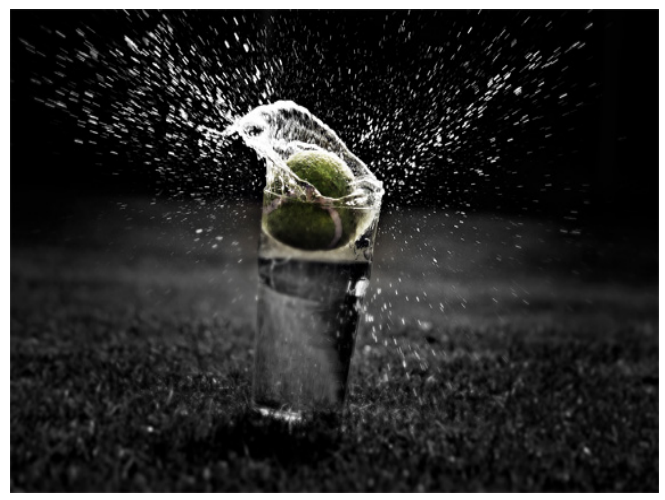

Gambar 2 Splash Warna (Alex Lewis)

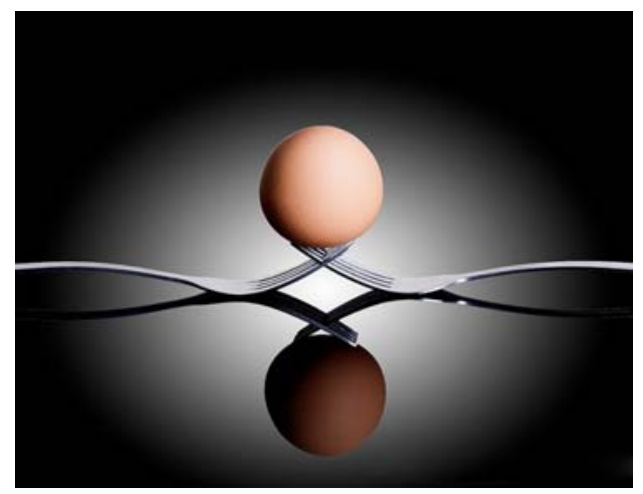

Gambar 3 Still Life

(Sumber: Unaiz, 2013)

Portrait fotografi; genre atau aliran ini merupakan salah satu aliran yang telah sangat dikenal oleh masyarakat dan merupakan salah satu aliran yang cukup lama mendominasi bidang fotografi sebelum genre yang lain berkembang sebanyak sekarang. Bahkan berdasarkan aliran fotografi portrait ini, banyak muncul aliran lain sebagai perkembangannya. Karena merupakan aliran yang relatif lama, definisi tentang aliran ini cukup banyak dan detail. Mayoritas berpendapat bahwa dalam foto portrait, 
pengamat diajak untuk mengamati lebih mendalam sosok yang muncul dalam potret tersebut, secara mayoritas bagian yang muncul didominasi oleh wajah dari model, namun foto potret yang bagus seharusnya bisa membuat model itu muncul secara berkarakter, bahkan menampilkan emosi dari pengamatnya.

Ada salah satu fotografer yang berpendapat: hampir mirip dengan foto Human Interest, Foto Portrait adalah foto yang berusaha membawa orang yang mengamati foto tersebut dapat masuk berempati dengan keadaan jiwa individu yang dijadikan sebagai objek atau subjek foto. Foto Portrait merupakan foto yang menggunakan wajah seseorang sebagai objek fotonya. Meskipun begitu, foto portrait bukanlah sekadar foto yang secara fisik menangkap wajah seseorang sebagai objek foto yang dipertimbangkan karena segi artistiknya. Foto portrait adalah jendela bagi suasana jiwa yang ada di dalam individu yang dijadikan sebagai subjek foto (Kamerafoto, 2011).
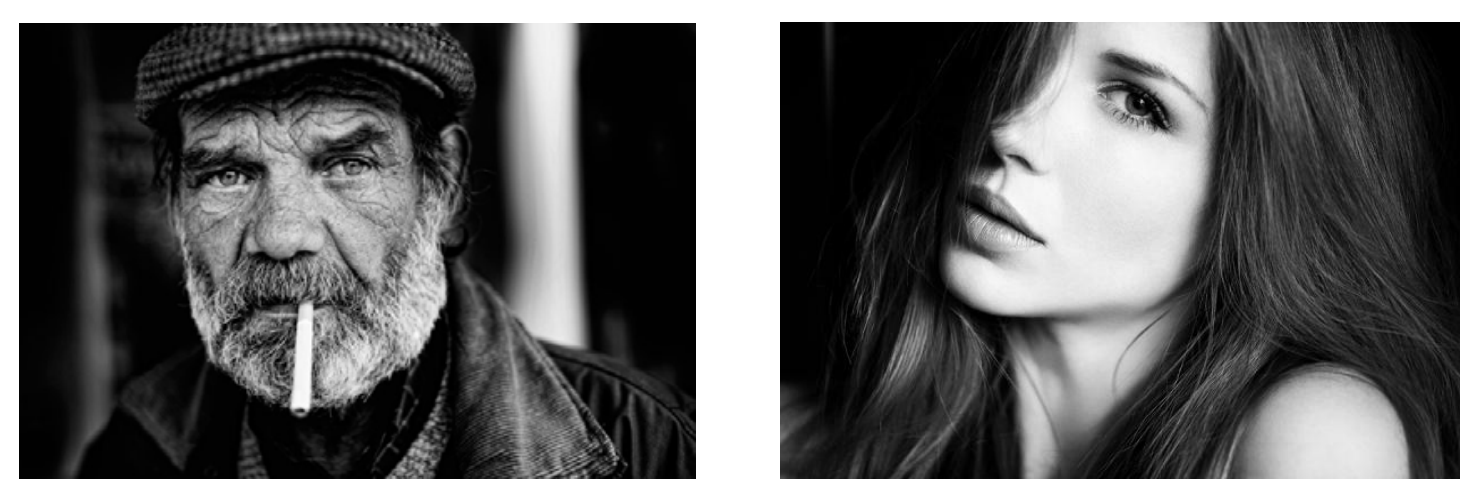

Gambar 4 Foto Portrait

(Ki: photo by Brett Harkness; Ka: photo by Jochen Drees)
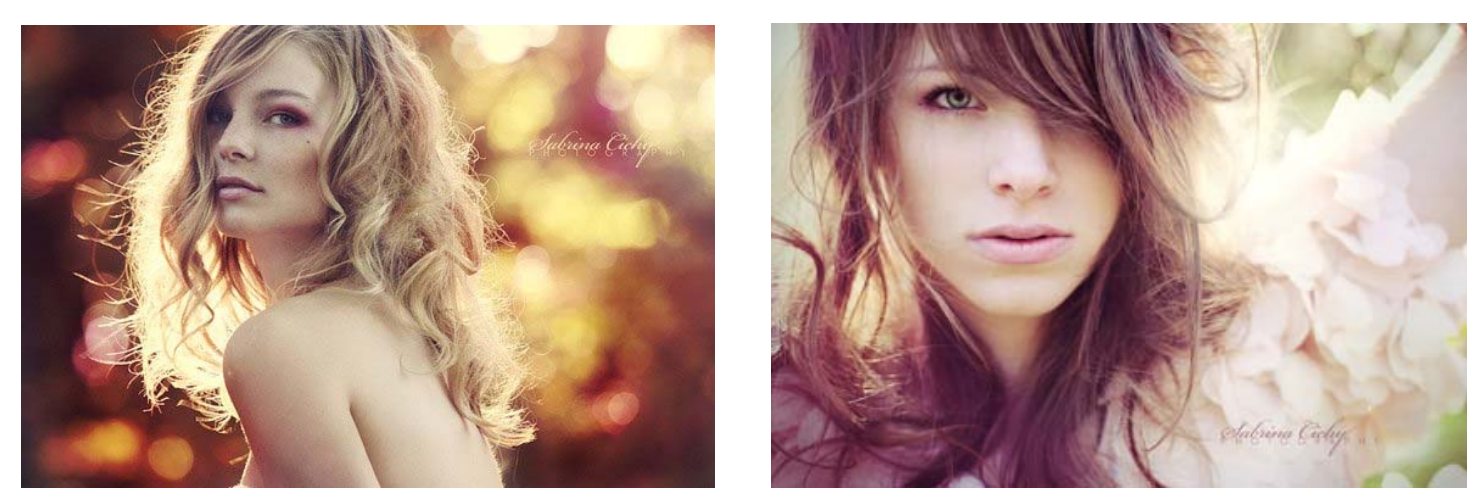

Gambar 5 Foto Portrait

(Sumber: Cichy, 2011)

Fotografi commercial advertising merupakan foto yang diambil untuk keperluan promosi, biasanya diatur saat pemotretan agar tampil lebih menarik dengan bantuan editing dan digital imaging di komputer grafik, dengan tujuan untuk menjual suatu produk, atau menjual ide. Makin bagus suatu karya foto di aliran ini, akan diikuti dengan kenaikan jumlah konsumen yang tertarik atas keberhasilan foto yang menjual tadi. 

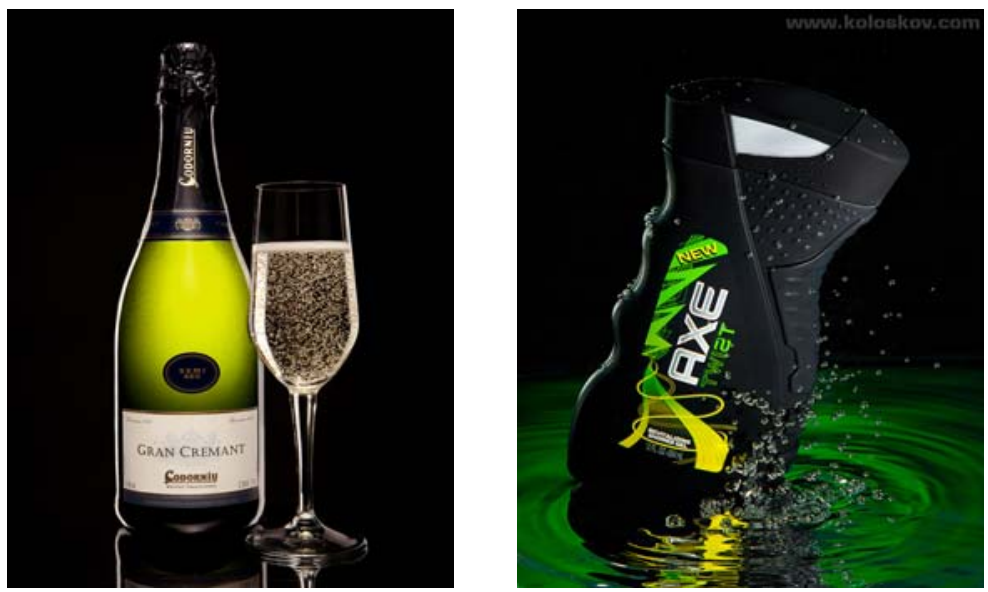

Gambar 6 Fotografi Commercial Advertising

(Ki: photo by Fabian Bernal Studios; Ka: photo by www.koloskov.com)

Fotografi Wedding; tipe ini merupakan salah satu aliran yang paling popular di kalangan masyarakat karena setiap orang pasti ingin memiliki foto yang bagus pada momen penting pernikahan mereka. Selain itu cabang dari genre atau aliran ini termasuk fotografi Prewedding, fotografi Candid, termasuk dokumentasi acara resepsinya sendiri, merupakan aliran fotografi yang tidak akan pernah hilang, dan akan selalu laku untuk dijadikan mata pencaharian oleh fotografer baik yang bekerja individu maupun dalam tim. Tipe ini membutuhkan fotografer yang berpengalaman dan peka karena dibutuhkan keahlian untuk menangkap momen-momen penting sebelum acara dalam prosesi pernikahan tersebut terlewatkan.

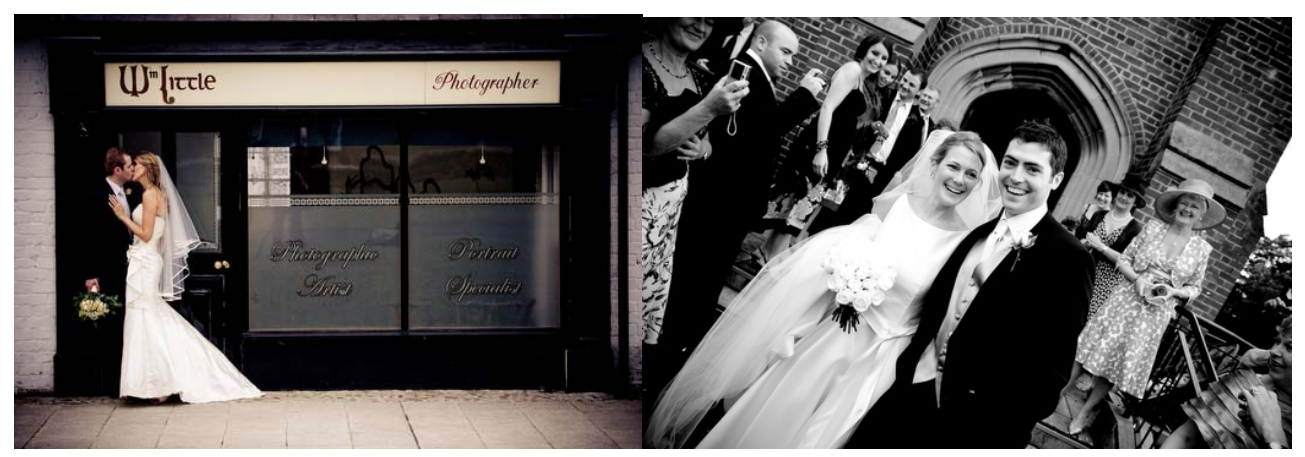

Gambar 7 Fotografi Wedding

(Desrowan Photographer)

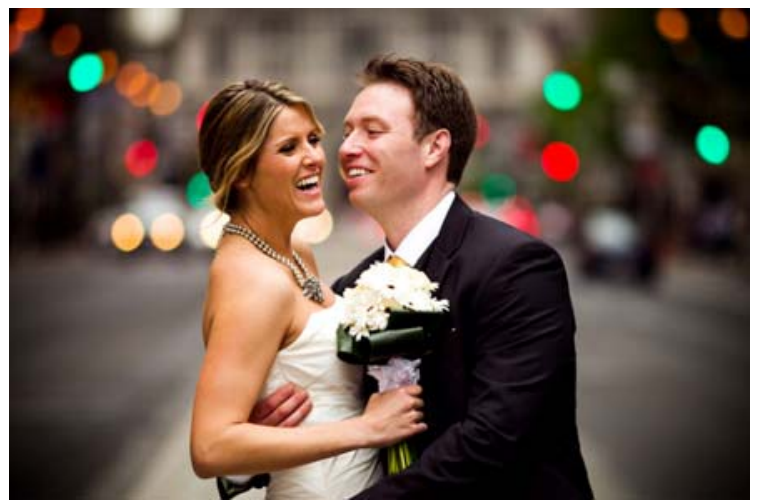

Gambar 8 Fotografi Wedding

(Shea Roggio Photographer) 
Fotografi Fashion; merupakan genre fotografi yang ditujukan untuk menampilkan pakaian dan barang-barang fashion lainnya. Sekilas, fashion photography dan portrait photography terlihat memiliki persamaan, sama-sama subjek fotonya adalah dominan orang, dan kedua jenis foto berusaha membuat fotonya terlihat menarik. Kesuksesan sebuah foto juga tergantung pada keterampilan fotografer, pengetahuan fotografer atas gaya pakaian, make-up dan juga tim yang menunjang, seperti make-up artist, hair stylist, koreografer dan sebagainya.

Bagaimanapun, banyak perbedaan mendasar antara fotografi portrait dengan fotografi fashion. Fashion photography bertujuan untuk membuat kostum yang di desain terlihat menarik sehingga orang ingin membelinya, sedangkan portrait fotografer bertujuan untuk menonjolkan karakter dan kepribadian dari subjek foto. Dalam upayanya, pengetahuan fotografer akan pencahayaan menjadi penting. Misalnya untuk menonjolkan tekstur sebuah baju, fotografer mengunakan cahaya yang cukup keras dengan kontras yang cukup tinggi. Sedangkan untuk memunculkan karakter lembut dari subjek foto portrait, fotografer mengunakan cahaya yang lembut.
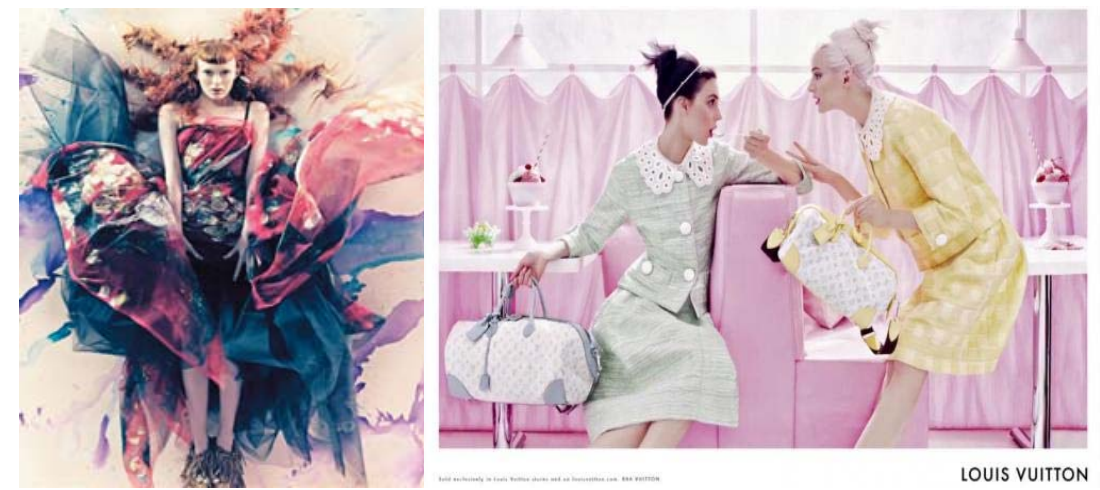

Gambar 9 Fotografi Fashion

(http://slappedbyfashion.com/fashion-photography/)

Fotografi Makanan (Food); sesuai dengan istilahnya fotografi makanan ini menampilkan objek foto makanan dalam berbagai jenis, dan kadang juga termasuk genre food and beverages. Pada awalnya aliran atau genre fotografi makanan ini merupakan bagian dari fotografi stillife, yang akirnya berkembang untuk kebutuhan komersial, dengan tujuan menghasilkan foto makanan yang nampak lezat dan juga menarik untuk tujuan advertising untuk dijadikan bagian dari desain kemasan, atau sebagai visual penunjang dalam buku menu, atau poster. Proses pemotretan makanan ini pada dasarnya butuh profesionalisme dalam konteks mendokumentasikan makanan yang tampak segar, dan menarik secara tampilan. Sehingga fotografer kadang membutuhkan bantuan foodstylish untuk mendandani objek fotonya agar tampak menarik. Namun belum tentu lezat bila dimakan.

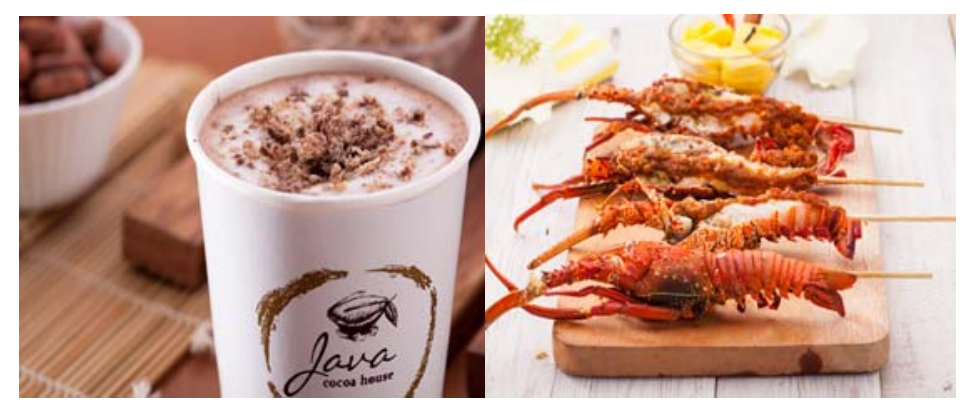

Gambar 10 Fotografi Makanan

(Marescotti Photography) 

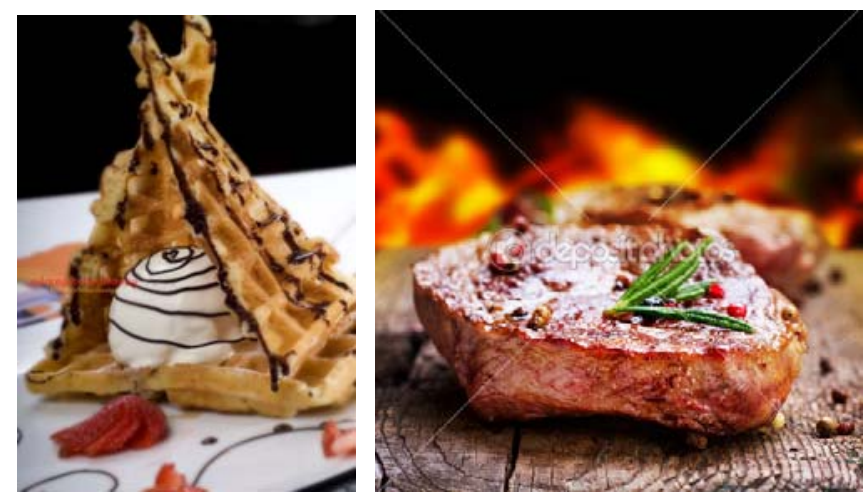

Gambar 11 Fotografi Makanan

(Ki: photo by Mirza Photography; Ka:

photo by http://depositphotos.com/11104172/stock-photo-Grilled-Steak-Barbecue)

Fotografi fine art; fotografi tipe ini biasanya memuat suatu visi atau konsep dari fotografernya, biasanya mengandung pesan atau maksud yang belum tentu secara langsung tersampaikan saat pengamat melihat foto tersebut. Salah satu komentar tentang fine art ini adalah karya foto yang cukup banyak sisi objektivitas dari fotografer. Pada dasarnya definisi fine art agak sulit untuk dijabarkan secara detail sebab banyak faktor hasil karya foto aliran ini yang mengandalkan kesan dan pengalaman emosi dari fotografer. Bisa disebutkan bahwa dalam aliran ini, elemen, komposisi, dan detail dalam sebuah frame yang muncul dalam visual foto, bisa bercerita lebih detail dari mata si fotografernya.

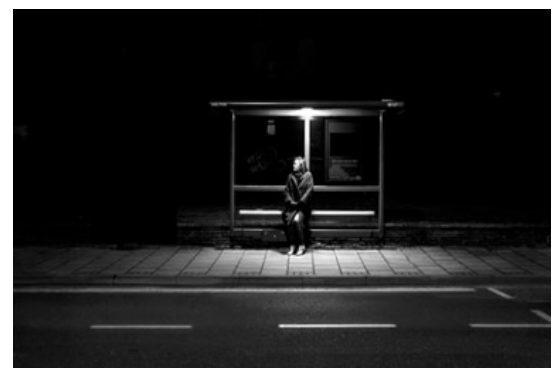

Gambar 12 Remain In Light by Rupert Vandervell

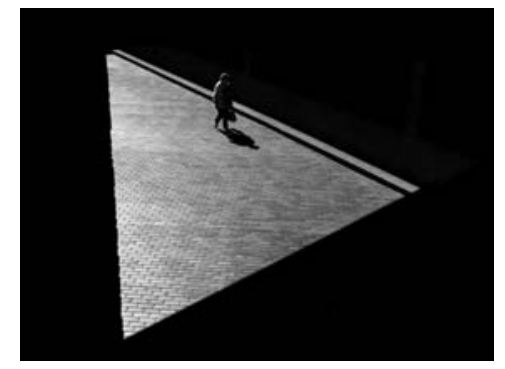

Gambar 13 Fragile by Rupert Vandervell

Fotografi Landscape; salah satu aliran yang sudah lama dikenal dalam bidang fotografi yang dalam karyanya mengabadikan alam yang ada, dengan segala kelebihannya yang umumnya menampilkan bagian yang cukup luas dari suatu lokasi.
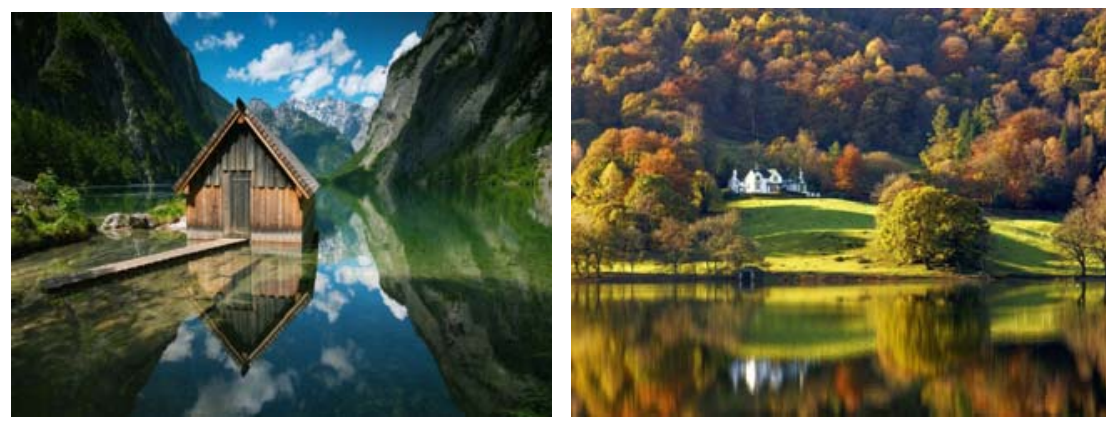

Gambar 14 Fotografi Landscape

(Ki: http://designyoutrust.com/2012/12/;

Ka: http://webneel.com/25-magnificent-natural-landscape) 
Fotografi Wildlife; jenis fotografi yang secara khusus merekam kegiatan-kegiatan dari hewan terutama hewan liar, yang membutuhkan waktu dan usaha yang cukup besar, terutama jika harus ke hutan-hutan atau ke padang pasir. Tidak banyak fotografer profesional di bidang ini. Karena tidak cukup jika sekadar hobi tanpa usaha dan tenaga yang sesuai, juga harus dilengkapi dengan peralatan yang memadai juga.
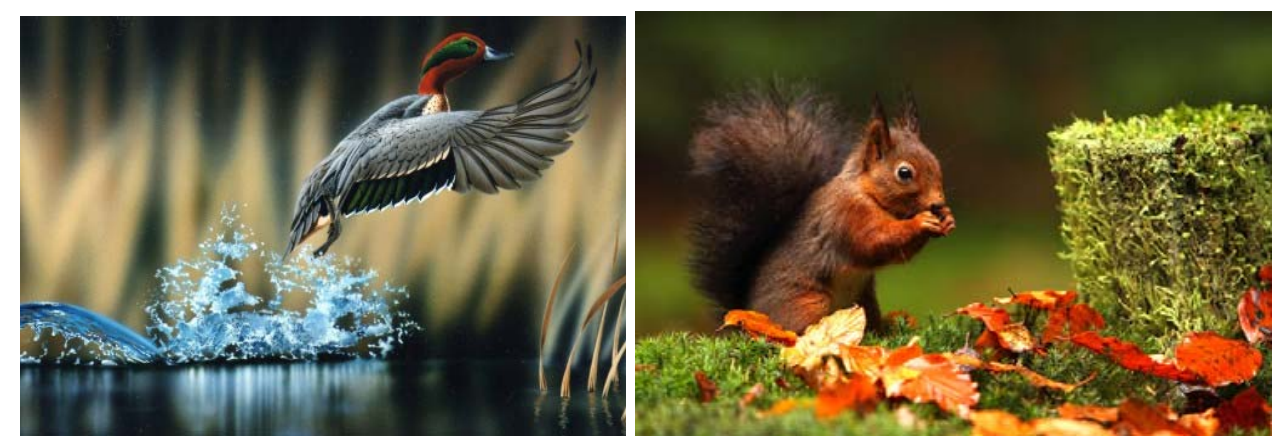

Gambar 15 Fotografi Wildlife

(Ki: http://stylegerms.com/wild-animals-photography/; Ka: http://photographyheat.com)

Fotografi makro; aliran ini membutuhkan lensa khusus yang mampu mengambil fokus di jarak yang sangat dekat dekat objek. Aliran ini cukup memiliki komunitas penggemar yang banyak yang didalami sebagai hobi. Ukuran objek fotonya relatif sangat kecil, bahkan bisa jauh lebih kecil dari lensa dan hasil foto si fotografer. Hasil karyanya pun merupakan hasil pembesaran yang umumnya sangat ekstrem dari ukuran awal objek tersebut.
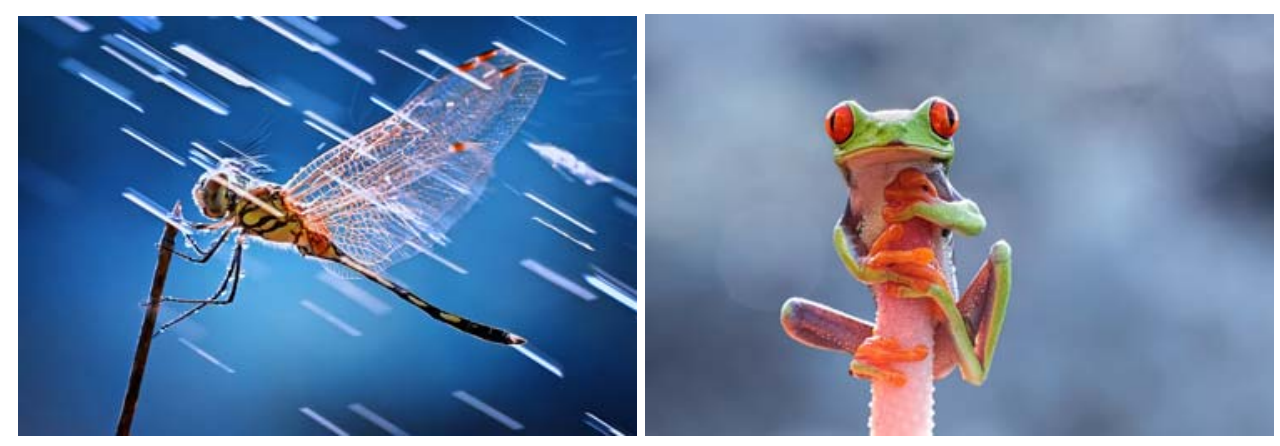

Gambar 16 Fotografi Makro

(Shikhei Goh)

\section{SIMPULAN}

Melalui kurun waktu yang sangat lama, bidang fotografi berkembang sangat cepat, dengan menghasilkan aliran-aliran atau genre yang menjadi bagian dalam perluasannya. Perkembangan genregenre tersebut tidak lepas dari campur tangan fotografer-fotografer yang menjadi pelaku seni dalam bidang ini. Dari konsep dan ide serta dari proses penciptaan mereka, maka karakter hasil karya fotografi semakin beragam dan makin luas. Ke depannya pasti perubahan dan pengembangan karya dari para fotografer ini masih akan menciptakan dan menambah aliran-aliran baru yang akan terus memperkaya bidang fotografi, terutama fotografi di tanah air. 


\section{DAFTAR PUSTAKA}

Bell, M. (2007). Master's Guide to Wedding Photography Capturing Unforgettable Moments and Lasting Impressions. Buffalo: Amherst Media.

Bella, N. (2012, 20 April). Aliran-aliran Photography. Diakses 28 Mei 2014 dari http://naomybella1.blogspot.com/

Cichy, S. (2011). Diakses dari http://www.eroglamour.com/2011/03/02/print:page,1,photographer-sabrinacichy.html

Felix, J. (April 2011). Penggunaan elemen visual garis dalam fotografi. Jurnal Humaniora, 2(1), 4857.

Freeman, M. (2007). The Photographer's Eye. Oxford: Focal Press

Kamerafoto. (2011). Pengertian Foto Portrait. Diakses dari http://kamerafoto.net/2011/04/pengertian-foto-portrait/

Muchtar, M. (2013, 7 November). Macam-macam Genre Fotografi. Diakses 28 Mei $2014 \quad$ dari http://www.idseducation.com/2013/11/07/macam-macam-genre-fotografi/

Unaiz. (2013, 18 Agustus). Still Life Photography - 30 Brilliant Shots. Diakses dari http://designgrapher.com/still-life-photography-30-brilliant-shots/

Vandervell, R. (2013). Man On Earth. Diakses 28 Mei 2014 dari http://www.rupertvandervell.co.uk/man-on-earth.html 